\title{
Considerable impacts of litter inputs on soil nematode community composition in a young Acacia crassicapa plantation
}

\author{
Cancan Zhao ${ }^{1}$, Yin $\mathrm{Li}^{1}$, Chenlu Zhang ${ }^{2,3, *}$, Yuan Miao ${ }^{1}$, Mengzhou Liu ${ }^{2,3}$, Wanlin Zhuang ${ }^{1}$, Yuanhu Shao ${ }^{2,3}$, \\ Weixin Zhang ${ }^{2,3}$, Shenglei $\mathrm{Fu}^{2,3},{ }^{*}$ \\ 1 International Joint Research Laboratory for Global Change Ecology, Laboratory of Biodiversity Conservation and Ecological Restoration, \\ School of Life Sciences, Henan University, Kaifeng 475004, China \\ 2 Key Laboratory of Geospatial Technology for the Middle and Lower Yellow River Regions, Ministry of Education, College of Environment \\ and Planning, Henan University, Kaifeng 475004, China \\ 3 Henan Key Laboratory of Integrated Air Pollution Control and Ecological Security, Kaifeng 475004, China
}

\section{H I G H L I G H T S}

- Nematodes was investigated in a young Acacia crassicapa plantation in southern China

- Both litter addition and root presence enhanced soil nematode abundance.

- Litter addition significantly altered soil nematode community composition.

- Root presence had a limited impact on nematode trophic group composition.

\section{ARTICLE INFO}

\section{Article history:}

Received December 8, 2020

Revised February 16, 2021

Accepted February 22, 2021

Keywords:

Litter addition

Root exudates

Nematode community composition

Soil depth

Nematode ecological index

\section{GRAPHICAL ABSTRACT}

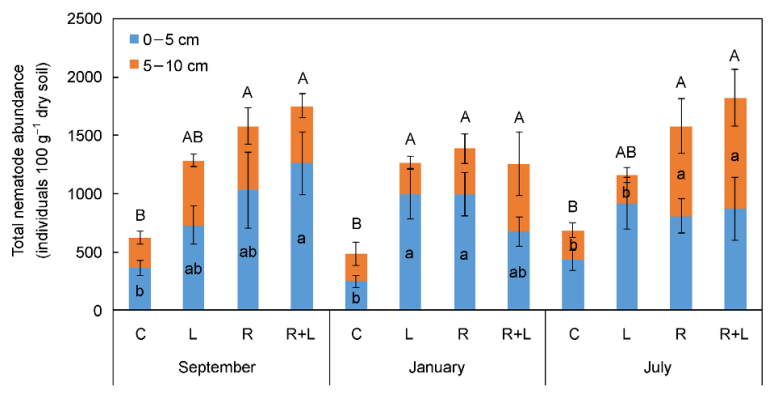

A B S T R A C T

Aboveground litter inputs and root exudates provide basal resources for soil communities, however, their relative contributions to soil food web are still not well understood. Here, we conducted a field manipulative experiment to differentiate the effects of litter inputs and living root on nematode community composition of surface and subsoils in a young Acacia crassicapa plantation in southern China. Our results showed that both litter addition and root presence significantly enhanced soil nematode abundance by $17.3 \%$ and $35.3 \%$, respectively. Litter addition altered nematode trophic group composition, decreased fungivore to bacterivore ratio, and enhanced maturity index and structure index, which led to a bacterial-based energy channel and a more complex food web structure. However, root presence had a limited impact on the nematode community composition and ecological indices. Despite nematodes surface assembly, soil depth did not affect nematode trophic group composition or ecological index. Our findings highlight the importance of litter inputs in shaping soil nematode community structure and regulating soil energy channel.

(c) Higher Education Press 2021

\footnotetext{
* Corresponding authors

E-mail address: zcl@vip.henu.edu.cn (C. Zhang);

fsI@henu.edu.cn (S. Fu)
} 


\section{Introduction}

There is little doubt that plants play a major role in structuring soil food web via creating their own habitat and regulating resource availability (Keith et al., 2009). In forest ecosystems, $80 \%-90 \%$ of the carbon fixed in tree tissue ultimately enters the decomposer food web (Bardgett et al., 2005). Tree-fixed carbon either reaches the soil via aboveground litter materials or via belowground root exudates, thereby fueling the soil food web (Pollierer et al., 2007).

In food web systems model, the litter based carbon channel seems to be the most important (Moore et al., 2004; Elfstrand et al., 2008; Freschet et al., 2013). Litter quantity and quality can impact soil biota directly as a resource or modify the habitat heterogeneity and soil properties, which indirectly affect the performance of soil biota (Kalinkat et al., 2013; Chen et al., 2020a; Zhao et al., 2021). Litter addition has been shown to increase, and conversely litter removal to decrease, the abundance of soil organisms and their diversity (Bastow, 2011; Sauvadet et al., 2016; Liu et al., 2019). In contrast, the negative and neutral effects of litter on soil biota were also found. Saj et al. (2009) have proposed that litter addition reduces the total number of bacterivorous and predatory nematodes. It has been reported that litter addition did not alter the abundance or diversity of soil nematodes or their carbon pool (Sayer, 2006; Pausch et al., 2018). The effects of litter on soil biota may vary with ecosystem type, litter quality and quantity, and experimental method.

Root exudates, as another important carbon input to the soil, can be decomposed within a few hours (Jones et al., 2005). The rapid use coupled with high local concentration of exudates around the roots leads to the rhizosphere effect (Ruf et al., 2006). A growing number of studies suggest that belowground rather than aboveground tree inputs have strong impacts on soil food web structure, especially in the short-term (Ruf et al., 2006; Kudrin, 2017). Using a ${ }^{13} \mathrm{C}$-labeling experiment, Pollierer et al. (2007) demonstrated that the majority of soil invertebrates obtain their carbon from roots. Similarly, root presence rather than shoot litter addition influenced nematode trophic group composition in a mesocosm experiment (Keith et al., 2009). However, the relative importance of aboveground and belowground resources to soil community composition remains less well understood.

It has been established that soil biota exhibits a typical depth differences, which often associates with variations in biotic factor of tree root and abiotic factors, such as organic matter content, oxidation-reduction potential, and soil $\mathrm{pH}$ (Lazarova et al., 2004; Stone et al., 2014; Moradi et al., 2020). Reductions of soil biota abundance and diversity and changes in the distribution of trophic group composition with increasing soil depth have been observed in several studies (Allison et al., 2007; Eilers et al., 2012; Tian et al., 2017). The role of the root-derived carbon seems to be even more important for soil biota in subsoil horizons (Potapov et al., 2017). Thus, study on depth differences of soil biota is needed for understanding the relative contribution of plant root.

Soil nematodes are the most abundant multi-cellular animal and play an important role in regulating microbial community and driving soil nutrient (De Long et al., 2016). Nematodes are effective indicators of soil community structure since they respond to disturbance rapidly, occupy several trophic levels in soil food webs, and can be divided into five ecologically trophic groups (Bongers and Ferris, 1999). The processes of bottom-up control in soil food web can be examined entirely within the soil nematode community. In addition, nematode ecological indices such as maturity index, structure index, and enrichment index, have been proved to be useful tools to assess ecosystem function (Neher and Darby, 2009; Zhao et al., 2016).

In the last few decades, intensively anthropogenic disturbances such as excessive deforestation and floor litter removal have greatly affected ecosystem function. A series of environmental problems of forest degradation and biodiversity loss continue to emerge. Artificial forests are established enormously in degraded habitats for ecological restoration during the past 40 years (Yang et al., 2009). Acacia crassicapa is an exotic species, and has high growth rates. Acacia crassicapa is commonly used as pioneer species for afforestation in southern China due to its tolerance to barren and acidic soils, and substantial nitrogen fixation ability (Zhao et al., 2018). In this study, we conducted a field manipulative experiment to differentiate the effects of leaf litter and living root on soil nematode community composition in a young Acacia crassicapa plantation. Given that root exudates are more labile and easily degradable than litter, we tested the first hypothesis that living root input is more important for shaping soil nematode community composition than litter. We proposed the second hypothesis that nematode community composition would change with soil depth due to the variation of resources. Fungivore and plant parasite nematodes may be decline with soil depth due to their dependence on plant roots.

\section{Material and methods}

\subsection{Site description and experimental design}

The experiment was carried out at Heshan National Field Observation and Research Station of Forest Ecosystem $\left(112^{\circ} 50^{\prime} \mathrm{E}, 22^{\circ} 34^{\prime} \mathrm{N}\right)$, which is located in Heshan city, Guangdong Province in southern China. The average altitude is $80 \mathrm{~m}$. The climate in this region is typical subtropical monsoon climate with a distinct wet and dry season. The mean annual precipitation is $1688 \mathrm{~mm}$ during 2005-2012 (Chen et al., 2019), with the rainy season from April to September. The mean annual evaporation is $1600 \mathrm{~mm}$. The mean annual temperature is $22.3^{\circ} \mathrm{C}$, ranged from $12.6^{\circ} \mathrm{C}$ in January to $29.2^{\circ} \mathrm{C}$ in July. The soil is classified as Ultisol developed from sandstone (Wan et al., 2015). The climax vegetation of the study area is monsoon evergreen broadleaved forest. However, most natural forests have degraded 
into abandoned hilly land due to long-term human disturbance.

The experiment was initiated in 2005 and used a complete randomized block design with four treatments, including: (1) no tree planted and no litter addition - abandoned hilly land as control (C); (2) no tree planted but with addition of $A$. crassicapa litter (L); (3) planted $A$. crassicapa but with litter removed from soil surface - with the tree root system intact (R); (4) planted A. crassicapa with the root and litter intact $(\mathrm{R}+$ $\mathrm{L})$. Each treatment was replicated six times with an area of $4 \times$ $6 \mathrm{~m}^{2}$ per plot. The distance between any two replicates was more than $1 \mathrm{~km}$. For the $L$ treatment, the $A$. crassicapa litters were collected from adjacent to the experimental area and added monthly as much as natural levels of litterfall. In the $R$ and $\mathrm{R}+\mathrm{L}$ treatments, $A$. crassicapa saplings were planted at a spacing of $2 \mathrm{~m} \times 3 \mathrm{~m}$. There were no significant difference in understory vegetation composition among all the treatments. To simulate shade of $A$. crassicapa tree and thus eliminate interference of light intensity under all treatments, artificially non-living trees were installed in the $C$ and $L$ treatments. No significant variation of photosynthetically active radiation was detected between $A$. crassicapa plantations and artificial trees conditions. When soil samples were taken in September 2007 (see the next section), $A$. crassicapa trees were three years old with an average height of $6.3 \mathrm{~m}$ and an average diameter at breast height of $64 \mathrm{~mm}$.

\subsection{Soil sampling and analysis}

Soil samples were collected from all the 24 plots for three times of September 2007, January 2008, and July 2008. In each plot, a soil auger (5-cm diameter, $10-\mathrm{cm}$ depth) was used to take samples at $0-5 \mathrm{~cm}$ and $5-10 \mathrm{~cm}$ depth. Four soil cores of the same depth were randomly taken in each plot and pooled into a single composite sample. Litter was removed from soil surface before soil samples were taken. After visible plant roots and stones were removed and the soil was passed through a 2-mm sieve, the samples were placed in an icebox and transported to laboratory.

Nematodes were extracted from $50 \mathrm{~g}$ of moist soil using the Baermann funnel method for $48 \mathrm{~h}$ (Barker, 1985). After preservation in $4 \%$ formalin solution, nematodes were placed in a counting chamber and counted with a stereomicroscope. In each sample, the first 100 individuals encountered were identified to genus with a DIC microscope $(400 \times)$, and classified into five trophic groups (bacterivore- $\mathrm{Ba}$, fungivore$\mathrm{Fu}$, plant parasite- $\mathrm{PP}$, predator- $\mathrm{Pr}$, and omnivore- $\mathrm{Om}$ ) and 16 functional guilds $\left(\mathrm{Ba}_{1}, \mathrm{Ba}_{2}, \mathrm{Ba}_{3}, \mathrm{Ba}_{4}, \mathrm{Fu}_{2}, \mathrm{Fu}_{3}, \mathrm{Fu}_{4}, \mathrm{PP}_{2}\right.$, $\mathrm{PP}_{3}, \mathrm{PP}_{4}, \mathrm{PP}_{5}, \mathrm{Pr}_{3}, \mathrm{Pr}_{4}, \mathrm{Pr}_{5}, \mathrm{Om}_{4}$, and $\mathrm{Om}_{5}$; Ferris et al., 2001). All nematodes were identified when the sample contained fewer than 100 individuals.

Soil organic carbon was measured by the oxidation of $\mathrm{H}_{2} \mathrm{SO}_{4} / \mathrm{K}_{2} \mathrm{CrO}_{7}$ and titration with $\mathrm{FeSO}_{4}$. Total nitrogen was measured using an ultraviolet spectrophotometer after Kjeldahl digestion. Gravimetric soil moisture was measured by the oven-drying method for $12 \mathrm{~h}$ at $105^{\circ} \mathrm{C}$. Soil $\mathrm{pH}$ was determined in a soil water mixture of 1:2.5 ratio (w/v) using a digital $\mathrm{pH}$ meter.

\subsection{Data analysis}

Maturity index (MI) was calculated as follows:

$$
\mathrm{MI}=\Sigma[v(i) \times f(i)]
$$

where $v(i)$ is the c-p value of free-living taxa $i$ and $f(i)$ is the proportion of that taxa of the total number of free-living nematodes in a sample. Low and high values of maturity index represent highly disturbed and highly stable soil ecosystem, respectively (Bongers, 1990).

Nematode channel ratio (NCR) was calculated as follows:

$$
\mathrm{NCR}=B a /(B a+F u)
$$

where $\mathrm{Ba}$ is bacterivore nematode abundance, and $\mathrm{Fu}$ is fungivore nematode abundance. The NCR indicates the relative importance of bacterivore and fungivore channels in the soil decomposer food web.

Structure index (SI) and enrichment index (EI) were calculated as follows:

$$
\begin{aligned}
& \mathrm{SI}=100 \times s /(s+b) \\
& \mathrm{EI}=100 \times e /(e+b)
\end{aligned}
$$

where $b$ is the basal food web component $\left(\mathrm{Ba}_{2}, \mathrm{Fu}_{2}\right), e$ is the enrichment component $\left(\mathrm{Ba}_{1}, \mathrm{Fu}_{2}\right)$, and $s$ is the structure component $\left(\mathrm{Ba}_{3}-\mathrm{Ba}_{5}, \mathrm{Fu}_{3}-\mathrm{Fu}_{5}, \mathrm{Pr}_{2}-\mathrm{Pr}_{5}, \mathrm{Om}_{4}-\mathrm{Om}_{5}\right)$. High $\mathrm{El}$ and $\mathrm{SI}$ indicate an enriched environment, and a complex or stable food web, respectively (Zhao et al., 2015a).

All the data were analyzed through a repeated measures ANOVA to determine the effects of litter addition, root presence, soil depth, sampling time, and their potential interaction on nematode and soil properties. The multiple comparisons based on one-way ANOVA were used to compare the differences of nematode abundance and trophic group percentage among treatments. General linear regressions were performed to assess the relationships between nematode ecological indices and soil properties. ANOVA and regressions were performed using SPSS 22.0 (SPSS Inc., Chicago, IL, USA). Redundancy analysis (RDA) were performed using Canoco 4.5 (Ithaca, NY, USA) to evaluate the associations of soil nematode community composition with soil properties.

\section{Results}

\subsection{Nematode community composition}

Litter addition increased the total nematode abundance by $17.3 \%$ than no litter addition, while root presence significantly increased the total nematode abundance by $35.3 \%$ than no root (Fig. 1, Table 1). Multiple comparison showed $R$ and $R+L$ treatments enhanced total nematode abundance than $C$ 
treatment at all sampling times. Mean nematode abundance at $0-5 \mathrm{~cm}$ depth (776.5 individuals $100 \mathrm{~g}^{-1}$ dry soil) was higher than that at $5-10 \mathrm{~cm}$ (462.3 individuals $100 \mathrm{~g}^{-1}$ dry soil). No effect of sampling time on nematode abundance was detected (Fig. 1, Table 1).

Litter addition significantly enhanced bacterivore, predator, and omnivore percentage by $7.9 \%, 123.9 \%$, and $31.3 \%$, whereas suppressed fungivore percentage by $26.6 \%$ than no litter addition. Root presence increased predator percentage by $492.3 \%$ than no root (Fig. 2, Table 1). Treatment of $L$ increased bacterivore but decreased fungivore percentage than $C$ treatment at all sampling times. $R$ and $R+L$ treatments had little influence on bacterivore or fungivore percentage at the first two sampling times. Soil depth did not have obvious effect on the relative abundance of any trophic group. Fungivore and plant parasite percentage showed a temporal variation (Fig. 2, Table 1).

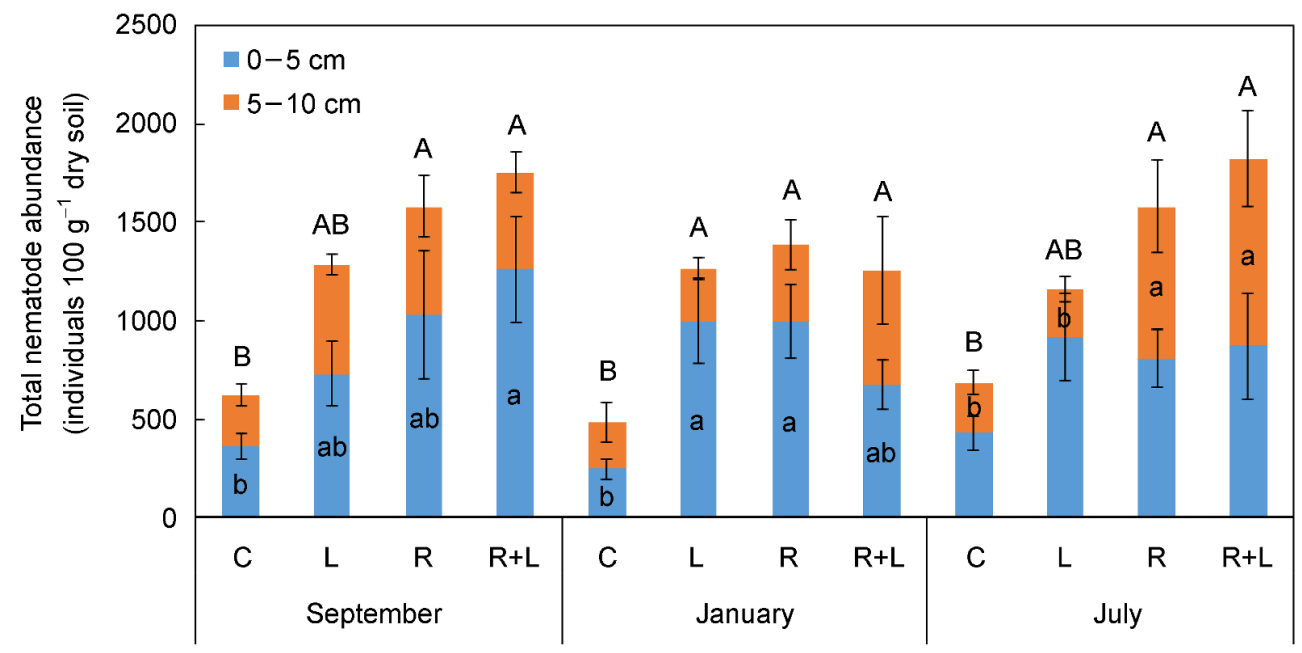

Fig. 1 Total nematode abundance under the four treatments at $0-5 \mathrm{~cm}$ and $5-10 \mathrm{~cm}$ depths in each sampling time (means \pm S.E., $n=6)$. C, $\mathrm{L}, \mathrm{R}$, and $\mathrm{R}+\mathrm{L}$ represent control, litter addition, intact root, and intact root and litter, respectively.

Table 1 The results ( $P$ values) of repeated measures ANOVAs for the effects of litter addition (L), root presence (R), soil depth (D), sampling time $(\mathrm{T})$, and their interactions on the soil nematode properties.

\begin{tabular}{lccccccccccc}
\hline & $\mathrm{NA}$ & $\mathrm{Ba} \%$ & $\mathrm{Fu} \%$ & $\mathrm{PP} \%$ & $\mathrm{Pr} \%$ & $\mathrm{Om} \%$ & $\mathrm{Ml}$ & $\mathrm{NCR}$ & $\mathrm{SI}$ & $\mathrm{EI}$ \\
\hline $\mathrm{L}$ & $\mathbf{0 . 0 2 6}$ & $<\mathbf{0 . 0 0 1}$ & $<\mathbf{0 . 0 0 1}$ & 0.921 & $\mathbf{0 . 0 1 7}$ & $\mathbf{0 . 0 1 7}$ & $<\mathbf{0 . 0 0 1}$ & $<\mathbf{0 . 0 0 1}$ & $<\mathbf{0 . 0 0 1}$ & $\mathbf{0 . 0 0 1}$ \\
$\mathrm{R}$ & $<\mathbf{0 . 0 0 1}$ & 0.612 & 0.165 & 0.990 & $<\mathbf{0 . 0 0 1}$ & 0.310 & $\mathbf{0 . 0 0 5}$ & 0.227 & $\mathbf{0 . 0 1 0}$ & $\mathbf{0 . 0 2 3}$ \\
$\mathrm{D}$ & $<\mathbf{0 . 0 0 1}$ & 0.480 & 0.509 & 0.115 & 0.952 & 0.441 & 0.169 & 0.521 & 0.379 & 0.790 & $\mathbf{< 1}$ \\
$\mathrm{T}$ & 0.454 & 0.161 & $\mathbf{0 . 0 1 2}$ & $\mathbf{0 . 0 3 0}$ & 0.092 & 0.680 & $<\mathbf{0 . 0 0 1}$ & $\mathbf{0 . 0 1 3}$ & $\mathbf{0 . 0 0 1}$ & $\mathbf{0 . 0 0 2}$ \\
$\mathrm{L} \times \mathrm{R}$ & 0.115 & $<\mathbf{0 . 0 0 1}$ & $<\mathbf{0 . 0 0 1}$ & 0.077 & $\mathbf{0 . 0 2 1}$ & $\mathbf{0 . 0 0 3}$ & $\mathbf{0 . 0 0 8}$ & $<\mathbf{0 . 0 0 1}$ & $<\mathbf{0 . 0 0 1}$ & $\mathbf{0 . 0 0 4}$ \\
$\mathrm{L} \times \mathrm{D}$ & 0.147 & 0.204 & 0.487 & 0.843 & 0.618 & 0.479 & 0.211 & 0.429 & 0.371 & 0.665 \\
$\mathrm{~L} \times \mathrm{T}$ & 0.975 & 0.435 & 0.403 & 0.830 & 0.073 & 0.198 & 0.192 & 0.350 & $\mathbf{0 . 0 1 7}$ & 0.796 \\
$\mathrm{R} \times \mathrm{D}$ & 0.779 & 0.238 & 0.099 & 0.374 & 0.797 & 0.285 & 0.403 & 0.095 & 0.323 & 0.282 \\
$\mathrm{R} \times \mathrm{T}$ & 0.474 & 0.948 & 0.199 & 0.404 & 0.145 & 0.190 & 0.062 & 0.218 & 0.463 & $\mathbf{0 . 0 0 5}$ \\
$\mathrm{D} \times \mathrm{T}$ & 0.354 & 0.666 & 0.722 & 0.696 & 0.776 & 0.705 & 0.358 & 0.729 & 0.174 & 0.934 \\
$\mathrm{~L} \times \mathrm{R} \times \mathrm{D}$ & $\mathbf{0 . 0 2 7}$ & 0.285 & 0.455 & 0.921 & 0.631 & 0.256 & 0.634 & 0.491 & 0.709 & 0.429 \\
$\mathrm{~L} \times \mathrm{R} \times \mathrm{T}$ & 0.524 & 0.217 & 0.511 & $\mathbf{0 . 0 2 5}$ & 0.069 & 0.385 & 0.205 & 0.537 & 0.310 & 0.543 \\
$\mathrm{~L} \times \mathrm{D} \times \mathrm{T}$ & 0.834 & 0.996 & 0.896 & 0.830 & 0.981 & 0.787 & 0.646 & 0.899 & 0.836 & 0.328 \\
$\mathrm{R} \times \mathrm{D} \times \mathrm{T}$ & 0.078 & 0.956 & 0.780 & 0.160 & 0.978 & 0.091 & 0.143 & 0.774 & 0.107 & 0.987 \\
$\mathrm{~L} \times \mathrm{R} \times \mathrm{D} \times \mathrm{T}$ & 0.249 & 0.220 & 0.390 & 0.696 & 0.921 & 0.226 & 0.545 & 0.349 & 0.724 & 0.548 \\
\hline
\end{tabular}

NA, total nematode abundance; Ba\%, bacterivores percentage; Fu\%, fungivores percentage; PP\%, plant parasites percentage; Pr\%, predators percentage; Om\%, omnivores percentage; MI, maturity index; NCR, nematode channel ratio; SI, structure index; El, enrichment index. 


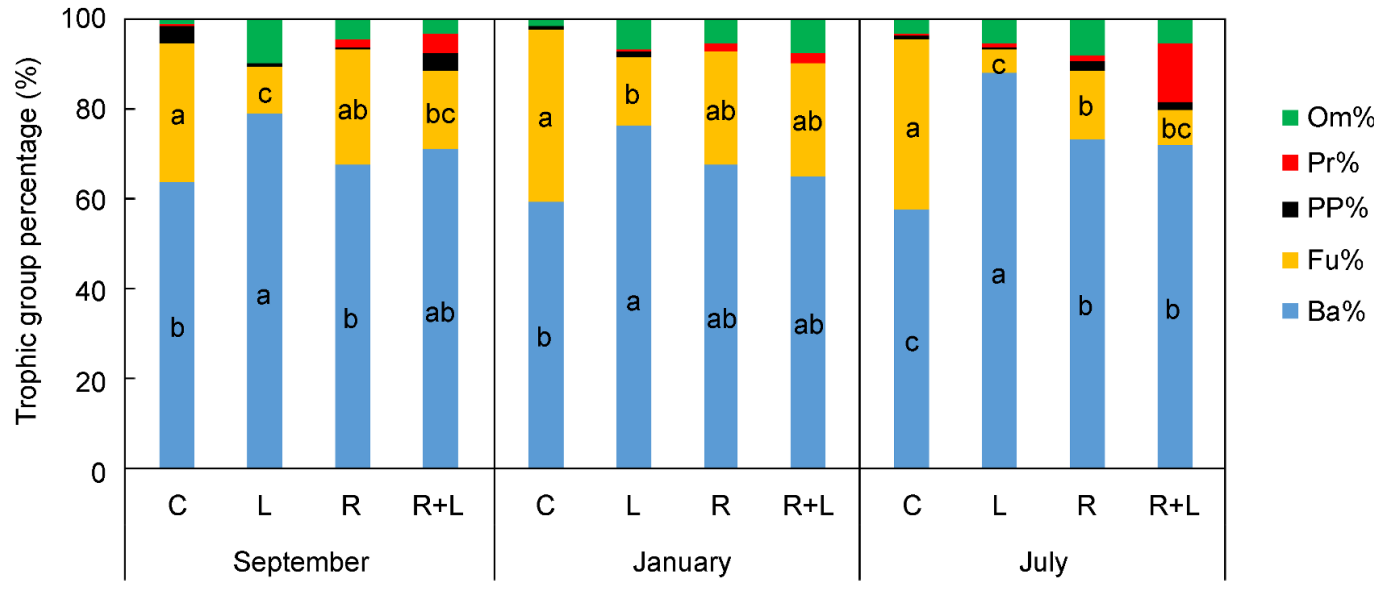

Fig. 2 Different nematode trophic groups percentage under the four treatments in each sampling time $(n=12)$. Average values of two soil layers were showed due to no significant soil depth effect on relative abundance of any trophic group. $C, L, R$, and $R+L$ represent control, litter addition, intact root, and intact root and litter, respectively. $\mathrm{Ba} \%, \mathrm{Fu} \%, \mathrm{PP} \%$, $\mathrm{Pr} \%$, and Om\% represent bacterivores percentage, fungivores percentage, plant parasites percentage, predators percentage, and omnivores percentage, respectively.

\subsection{Nematode ecological indices}

Litter addition significantly increased maturity index (Fig. 3A) and nematode channel ratio (Fig. 3B) than no litter addition.

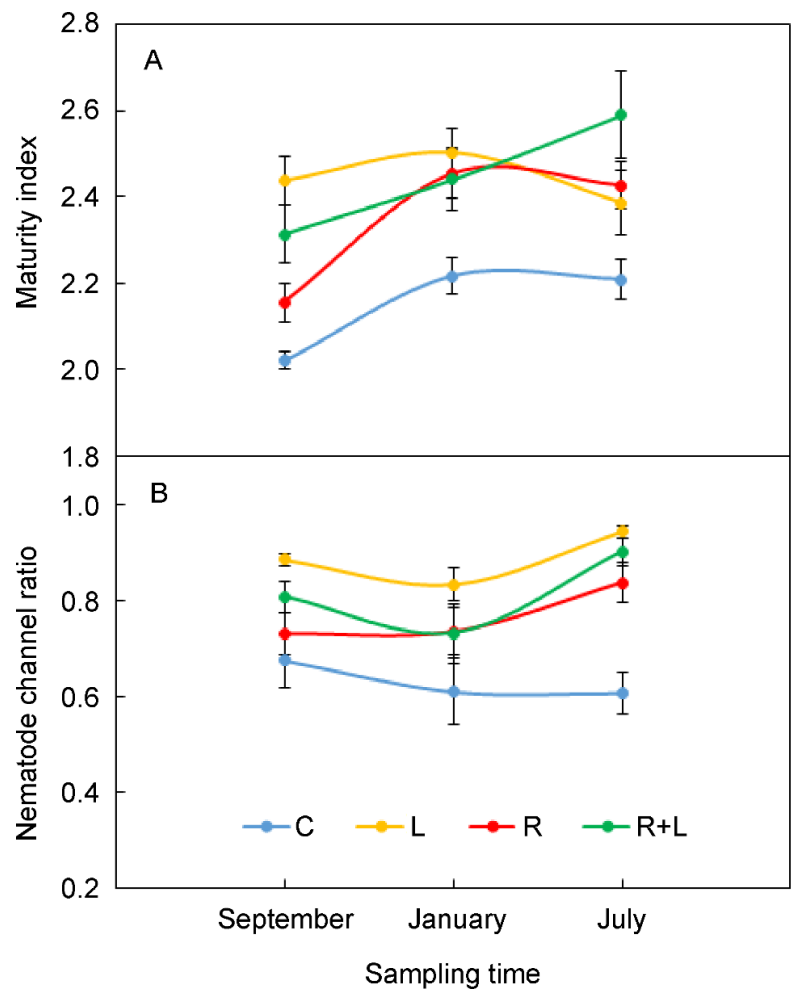

Fig. 3 Nematode maturity index (A) and nematode channel ratio $(B)$ under the four treatments in each sampling time (means \pm S.E., $n=12$ ). Average values of two soil layers were showed due to no significant soil depth effect on any ecological index. C, $\mathrm{L}, \mathrm{R}$, and $\mathrm{R}+\mathrm{L}$ represent control, litter addition, intact root, and intact root and litter, respectively.
Root presence increased maturity index (Fig. 3A, Table 1). Faunal analysis revealed that the control plots were clustered in quadrat $D$, while most plots of other treatments appeared in quadrat $C$ (Fig. 4), indicating more structured food web in the $L, R$, and $R+L$ treatments. Both litter addition and root presence elevated structure index, but suppressed enrichment index (Fig. 4, Table 1). All nematode ecological indices showed strong temporal variation (Table 1).

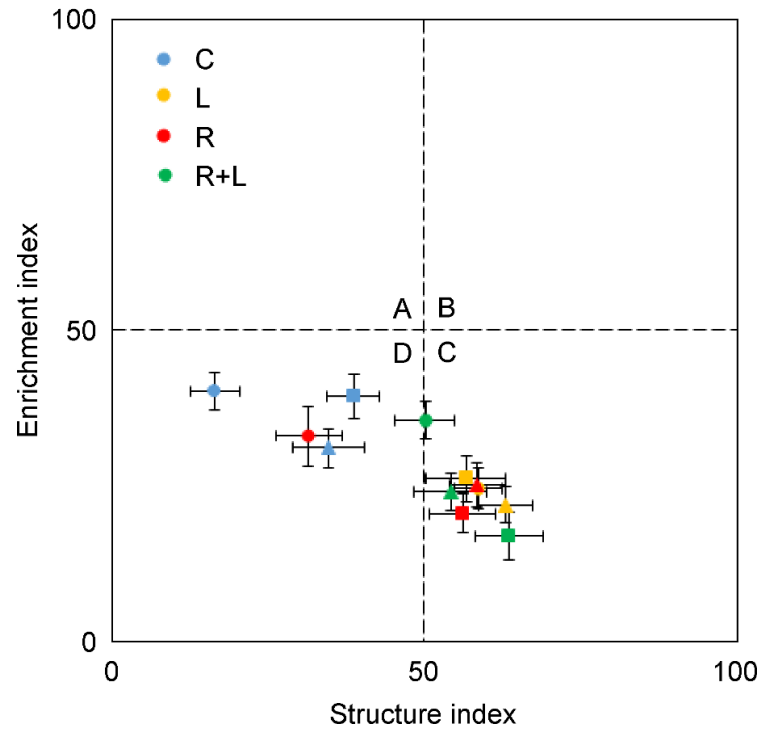

Fig. 4 Faunal analysis of soil nematode community under the four treatments in each sampling time (means \pm S.E., $n=12$ ). C, $L, R$, and $R+L$ represent control, litter addition, intact root, and intact root $\mathrm{t} 7799$ and litter, respectively. Circle, triangle, and square represent September, January, and July, respectively. 


\subsection{Soil properties}

Litter addition significantly increased soil organic carbon and total nitrogen by $23.1 \%$ and $19.3 \%$ than no litter addition, respectively, whereas root presence did not have obvious effect (Table 2). Soil organic carbon and total nitrogen at $0-5$ $\mathrm{cm}$ depth were much higher than those at $5-10 \mathrm{~cm}$. Litter addition increased soil moisture and decreased soil $\mathrm{pH}$ than no litter addition, conversely, root presence reduced soil moisture and increased soil $\mathrm{pH}$ than no root (Table 2). Soil pH at $0-5 \mathrm{~cm}$ depth was lower than that at $5-10 \mathrm{~cm}$. The temporal variations in soil organic carbon, soil moisture, and soil $\mathrm{pH}$ were observed (Table 2).
3.4 Relationships of nematodes with soil properties

The result of redundancy analysis showed that the variation of soil nematode community structure was explained $36 \%$ and $13 \%$ by RDA 1 and RDA2 axes, respectively. Data points for the $L$ and $R+L$ treatments were obviously separated from control (Fig. 5). RDA1 was highly related to soil moisture, total nitrogen, and soil organic carbon with correlation coefficient of $0.36,0.23$, and 0.20 , respectively. Maturity index linearly increased with soil moisture, soil organic carbon, and total nitrogen (Table 3). Nematode channel ratio showed a positive correlation with soil moisture. Structure index showed positive correlations with soil moisture and total nitrogen, while

Table 2 Means (means \pm S.E.) of soil properties for three sampling time and repeated measures ANOVAs results $(F$ values).

\begin{tabular}{|c|c|c|c|c|}
\hline & Soil organic carbon $\left(\mathrm{g} \mathrm{kg}^{-1}\right)$ & Total nitrogen $\left(\mathrm{g} \mathrm{kg}^{-1}\right)$ & Soil moisture (\%) & $\mathrm{pH}$ \\
\hline \multicolumn{5}{|l|}{$0-5 \mathrm{~cm}$} \\
\hline C & $18.73 \pm 2.16$ & $0.67 \pm 0.08$ & $17.04 \pm 1.19$ & $3.96 \pm 0.04$ \\
\hline L & $25.90 \pm 3.14$ & $0.83 \pm 0.08$ & $24.63 \pm 1.29$ & $3.84 \pm 0.02$ \\
\hline $\mathrm{R}$ & $19.00 \pm 1.31$ & $0.61 \pm 0.03$ & $16.57 \pm 1.51$ & $3.97 \pm 0.02$ \\
\hline$R+L$ & $24.74 \pm 2.97$ & $0.81 \pm 0.08$ & $19.17 \pm 1.90$ & $3.97 \pm 0.02$ \\
\hline \multicolumn{5}{|l|}{$5-10 \mathrm{~cm}$} \\
\hline C & $13.26 \pm 1.29$ & $0.49 \pm 0.05$ & $18.69 \pm 0.96$ & $4.05 \pm 0.03$ \\
\hline L & $15.00 \pm 1.36$ & $0.54 \pm 0.06$ & $22.90 \pm 1.25$ & $3.97 \pm 0.02$ \\
\hline $\mathrm{R}$ & $15.06 \pm 1.50$ & $0.51 \pm 0.04$ & $19.52 \pm 1.37$ & $4.00 \pm 0.02$ \\
\hline$R+L$ & $15.66 \pm 1.31$ & $0.55 \pm 0.04$ & $18.52 \pm 1.24$ & $4.02 \pm 0.01$ \\
\hline \multicolumn{5}{|l|}{ ANOVA } \\
\hline $\mathrm{L}$ & $7.939^{\star *}$ & $6.353^{*}$ & $24.677^{\star \star *}$ & $7.805^{\star *}$ \\
\hline $\mathrm{R}$ & 0.086 & 0.097 & $12.384^{* * *}$ & $5.150^{*}$ \\
\hline $\mathrm{D}$ & $29.487^{\star \star *}$ & $22.351^{* * *}$ & 0.666 & $21.125^{\star * *}$ \\
\hline $\mathrm{T}$ & $6.542^{\star *}$ & 0.433 & $68.711^{\star \star *}$ & $10.888^{* * *}$ \\
\hline $\mathrm{L} \times \mathrm{R}$ & 0.225 & 0.012 & $14.301^{* * *}$ & $9.846^{\star *}$ \\
\hline$L \times D$ & 3.817 & 2.525 & $6.726^{*}$ & 0.827 \\
\hline $\mathrm{L} \times \mathrm{T}$ & 2.386 & 1.433 & 0.293 & 1.241 \\
\hline $\mathrm{R} \times \mathrm{D}$ & 0.383 & 0.317 & 0.791 & $3.964^{*}$ \\
\hline $\mathrm{R} \times \mathrm{T}$ & 1.316 & 0.646 & $5.548^{\star *}$ & 3.006 \\
\hline $\mathrm{D} \times \mathrm{T}$ & 1.917 & 0.690 & 1.440 & 1.223 \\
\hline $\mathrm{L} \times \mathrm{R} \times \mathrm{D}$ & 0.003 & 0.102 & 0.006 & 0.005 \\
\hline $\mathrm{L} \times \mathrm{R} \times \mathrm{T}$ & 0.089 & 0.031 & 0.289 & 2.210 \\
\hline $\mathrm{L} \times \mathrm{D} \times \mathrm{T}$ & $3.259^{*}$ & 1.729 & 1.404 & 0.475 \\
\hline $\mathrm{R} \times \mathrm{D} \times \mathrm{T}$ & 0.048 & 0.008 & 0.583 & 0.139 \\
\hline $\mathrm{L} \times \mathrm{R} \times \mathrm{D} \times \mathrm{T}$ & 0.160 & 0.121 & 0.593 & 0.302 \\
\hline
\end{tabular}

Significance levels: ${ }^{*} P<0.05,{ }^{* *} P<0.01,{ }^{* * *} P<0.001$. 


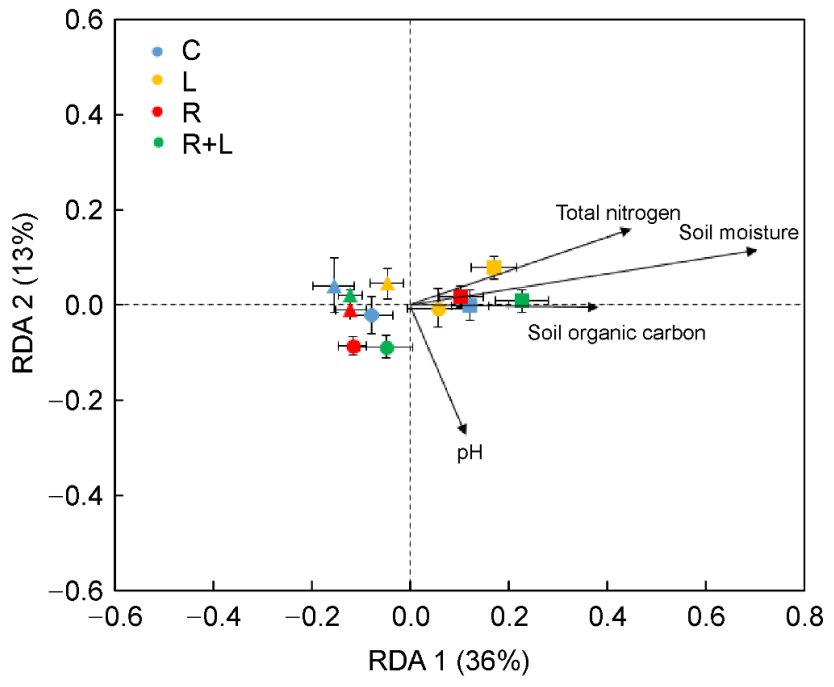

Fig. 5 Redundancy analysis (RDA) of the associations of soil nematode community composition (as indicated by functional guild) with soil properties (means \pm S.E., $n=12$ ). C, L, R, and R + $L$ represent control, litter addition, intact root, and intact root and litter, respectively. Circle, triangle, and square represent September, January, and July, respectively.

enrichment index showed negative correlations with soil moisture and total nitrogen (Table 3).

\section{Discussion}

We have demonstrated that both litter addition and root presence dramatically enhanced soil nematode abundance, suggesting the important roles of both aboveground and belowground resources input on soil nematodes. Litter addition but not root presence significantly altered nematode trophic group composition, which indicates litter input rather than root exudates would play more important role in shaping nematode composition in soil food webs.

\subsection{Effects of litter addition on soil nematode}

In the present study, litter addition significantly increased total nematode abundance, bacterivore, predator, omnivore percentage, soil organic carbon, and total nitrogen (Figs. 1, 2, Tables 1, 2, 3), suggesting a strong bottom-up effect of litter on soil nematode food web. This is consistent with findings of some previous studies (Elfstrand et al., 2008; Eisenhauer and Reich, 2012; Zhao et al., 2021). The positive effect of litter on soil nematode abundance may involve both direct and indirect ways. First, $A$. crassicapa tree which has lower leaf $\mathrm{C}: \mathrm{N}$ ratio, could produce a great quantity of litterfall and support more decomposers, including microorganisms and microbivores (Zhao et al., 2018). Secondly, in our study, earthworms as ecosystem engineers play a vital role in accelerating litter decomposition. Chen et al. (2020a) have reported that there are 145 earthworm individuals per $\mathrm{m}^{2}$ in our experimental site. Litter removal could decrease the density of earthworm by $58 \%$ (Chen et al., 2020a). Such a large number of earthworms could burrow, mix litter and soil, consume soil materials, excrete feces, and subsequently accelerate nutrient cycling and support soil nematodes (Shao et al., 2017; Eisenhauer et al., 2019). Most inconsistent results, which suggest litter have limited impact, are derived from no earthworm microcosm or mesocosm experiment (Ruf et al., 2006; Keith et al., 2009), which could not veritably reflect the natural condition of ecosystem. Thirdly, litter not only directly provides a resource to soil nematodes, but also alters environmental conditions including habitat structure and microclimate, then indirectly influences soil nematodes (Zhang et al., 2018). Litter could form a protective layer on the soil surface and provide shelter for soil microfauna (Keith et al., 2009). In our study, litter addition improved soil moisture by $18.7 \%$ due to slower evaporation (Table 2), which facilitates nematode population growth (Zhang et al., 2019).

Litter addition decreased fungivore percentage, and increased bacterivore and omnivore-predator percentage (Figs. 2, 4, Table 1), indicating that litter may be central in shaping nematode trophic composition in soil food webs. Lower fungivore to bacterivore ratio in litter addition treatment is inconsistent with most previous studies (Wang et al., 2013; Malik et al., 2016). One possible explanation may be that the ecosystem in our study is seriously disturbed and degraded. Extensive deforestation have caused soil labile carbon depleted. Aboveground litter input could stimulate more bacteria and bacterivore nematodes growth at the initial stage of restoration. The higher soil moisture may be another reason for lower relative abundance of fungivores due to bacterial dependence on water and fungal drought resistance (Fig. 5, Tables 2, 3; Briar et al., 2012; Zhao et al., 2015b). In line with the changes in fungivore and bacterivore percentage, litter addition increased nematode channel ratio (Fig. 3B, Table 1), indicating that litter can cause a switch from the fungal-based to the bacterial-based energy channel, i.e.,

Table 3 Spearman correlation coefficients of the relationship between nematode ecological indices and soil properties.

\begin{tabular}{lllll}
\hline & Maturity index & Nematode channel ratio & Structure index & Enrichment index \\
\hline Soil moisture & $0.242^{* *}$ & $0.260^{* *}$ & $0.226^{* *}$ & $-0.176^{*}$ \\
Soil organic carbon & $0.168^{*}$ & 0.110 & 0.131 & -0.041 \\
Total nitrogen & $0.233^{* *}$ & 0.088 & $0.176^{*}$ & $-0.176^{*}$ \\
\hline
\end{tabular}

Significance levels: ${ }^{*} P<0.05,{ }^{* *} P<0.01$. 
accelerate soil energy flow (Rooney et al., 2006; Zhao et al., 2019). Moreover, litter addition enhanced maturity index and structure index (Figs. 3, 4, Tables 1,3), suggesting a more complex food web structure and trophic links (Ferris et al., 2001).

\subsection{Effects of root presence on soil nematode}

Root presence profoundly enhanced total nematode abundance, however, had a limited impact on the nematode trophic group composition (Figs. 1, 2, 5, Table 1). These findings are inconsistent with our first hypothesis and the widespread assumption that root-derived resources serve as driver of soil food web dynamics (Keith et al., 2009; Zhang et al., 2018). In general, living root exudates mainly consist of easily degradable organic compounds including carbohydrates, $\mathrm{N}$ free carbonic acids, and amino acids (Gransee and Wittenmayer, 2000). These compounds could stimulate bacteria and bacterial-feeding nematodes growing (Rooney et al., 2006). Furthermore, roots of $A$. crassicapa (legume) could form symbioses with soil nitrogen-fixing bacteria, resulting in bacterial dominance and energy channel (Zhao et al., 2018). Our uncommon findings could be interpreted in four ways. First, planting $A$. crassicapa in abandoned land may increase plant diversity, then shift toward more fungal-dominated communities (Eisenhauer et al., 2011; Eisenhauer et al., 2017; Zhao et al., 2019). Secondly, root presence treatment have significantly decreased soil moisture, thereby suppress the relative bacterial energy channel to some extent (Table 2, Fig. 5; Kaneda and Kaneko, 2011; Sun et al., 2020a). Thirdly, roots provide carbon sources for soil communities, meanwhile compete for available and labile nutrients with bacteria and bacterivores to support the fast-growing of $A$. crassicapa (Bardgett et al., 2014). Finally, root presence have obviously enhanced relative abundance of predatory nematode, while their top-down effects on microbivores could result in stable bacterivore and fungivore percentage. Therefore, root presence can maintain the energy channel balance and do not change the nematode community composition in our study.

\subsection{Different effects of litter and root}

Soils comprise two major food chains, litter or detritus based and root based (Glavatska et al., 2017). In detritus-based food chain, litter as dead organic matter fuels the bacterial and fungal energy channel. While in root-based food chain, the predominant carbon sources are living plant tissue and root exudates (Ruess and Ferris, 2004). In our study, litter addition altered nematode community composition via changing relative bacterivore and fungivore abundance, i.e., through detritus-based food chain. However, in the root presence plots, the rhizosphere associated food web comprise both herbivore and detritivore food chain, which are more complex compared to detritus food web (Bais et al., 2006). Plant parasitic nematodes accounted for a small percentage of total nematode abundance in our study, and were not influenced by root presence (Table 1, Fig. 2). Lower root-based energy fluxes and complicated species interactions in the rhizosphere are the causes of limited impact of living root on soil nematodes community structure.

\subsection{Effects of soil depth on soil nematode}

Soil nematode abundance, soil organic carbon, and total nitrogen in the surface soils were higher than those in the subsoils (Fig. 1, Tables 1, 2). This surface assembly pattern has also been found in many previous studies (Zhang et al., 2010; Zhao et al., 2015a; Scharroba et al., 2016). Most of soil organic matter, which consist of leaf litter and root exudates, are accumulated at the surface layer as principal source for nematodes (De Long et al., 2016; Hsiao et al., 2018). In addition, oxygen is more favorable for microbial and nematode growth in the surface than in the subsoils (Sun et al., $2020 b$ ). Soil depth have no impact on nematode trophic group composition or any ecological index (Table 1), which is in contrast to our second hypothesis. A few studies have reported that soil microbial community shift with depth along with a decline in fungal/bacterial ratio, because fungi are often associated with plant roots and concentrated in the surface soils (Sradnick et al., 2014; Stone et al., 2014). No variation in nematode community composition in our study may be attributed to the homogenization of nutrients and living conditions among soil layers. The vertical distribution of soil communities depend on soil texture (Sradnick et al., 2014; Hsiao et al., 2018). Sandy soil in our experimental site may lead to little protected organic matter in soil aggregates, which facilitate nutrients of surface leaching into deeper (Chen et al., 2020b; Moradi et al., 2020). In addition, soil depth have not influenced soil moisture (Table 2), resulting in similar environmental condition.

\section{Conclusion}

Strong bottom-up effects of both aboveground litter and root exudates on soil food web are confirmed in the study. The results highlight that aboveground litter may be more important in shaping soil nematode community structure than belowground inputs in young Acacia crassicapa plantation. Therefore, future studies should not overlook the litter inputs, especially in degraded ecosystem. Floor litter should not be removed from artificial forests during early restoration. The study provides data and theoretical support for plantation management in southern China.

\section{Acknowledgments}

This study was supported by the NSFC-Henan Joint Fund (U1804101, U1904204), Henan Key Scientific and Technological Project (192102110160), the National Natural Science Foundation of China (31800405), Innovation Scientists and Technicians Troop Construction Projects of Henan Province. 


\section{References}

Allison, V.J., Yermakov, Z., Miller, R.M., Jastrow, J.D., Matamala, R., 2007. Using landscape and depth gradients to decouple the impact of correlated environmental variables on soil microbial community composition. Soil Biology \& Biochemistry 39, 505-516.

Bais, H.P., Weir, T.L., Perry, L.G., Gilroy, S., Vivanco, J.M., 2006. The role of root exudates in rhizosphere interactions with plants and other organisms. Annual Review of Plant Biology 57, 233-266.

Bardgett, R.D., Bowman, W.D., Kaufmann, R., Schmidt, S.K., 2005. A temporal approach to linking aboveground and belowground ecology. Trends in Ecology \& Evolution 20, 634-641.

Bardgett, R.D., Mommer, L., de Vries, F.T., 2014. Going underground: root traits as drivers of ecosystem processes. Trends in Ecology \& Evolution 29, 692-699.

Barker, K.R., 1985. Nematode extraction and bioassays, in: Barker, K. R., Carter, C.C., Sasser, J.N., eds., An advanced treatise on Meloidogyne. vol. 2. North Carolina State University Graphics, Raleigh, pp. 19-35. Methodology.

Bastow, J.L., 2011. Facilitation and predation structure a grassland detrital food web: the responses of soil nematodes to isopod processing of litter. Journal of Animal Ecology 80, 947-957.

Bongers, T., 1990. The maturity index: an ecological measure of environmental disturbance based on nematode species composition. Oecologia 83, 14-19.

Bongers, T., Ferris, H., 1999. Nematode community structure as a bioindicator in environmental monitoring. Trends in Ecology \& Evolution 14, 224-228.

Briar, S.S., Culman, S.W., Young-Mathews, A., Jackson, L.E., Ferris, H., 2012. Nematode community responses to a moisture gradient and grazing along a restored riparian corridor. European Journal of Soil Biology 50, 32-38.

Chen, H., Dai, Z., Veach, A.M., Zheng, J., Xu, J., Schadt, C.W., 2020b. Global meta-analyses show that conservation tillage practices promote soil fungal and bacterial biomass. Agriculture, Ecosystems \& Environment 293, 106841.

Chen, Y., Cao, J., He, X., Liu, T., Shao, Y., Zhang, C., Zhou, Q., Li, F., Mao, P., Tao, L., Liu, Z., Lin, Y., Zhou, L., Zhang, W., Fu, S., 2020a. Plant leaf litter plays a more important role than roots in maintaining earthworm communities in subtropical plantations. Soil Biology \& Biochemistry 144, 107777.

Chen, Y., Zhang, Y., Cao, J., Fu, S., Hu, S., Wu, J., Zhao, J., Liu, Z., 2019. Stand age and species traits alter the effects of understory removal on litter decomposition and nutrient dynamics in subtropical Eucalyptus plantations. Global Ecology and Conservation 20, e00693.

De Long, J.R., Laudon, H., Blume-Werry, G., Kardol, P., 2016. Nematode community resistant to deep soil frost in boreal forest soils. Pedobiologia 59, 243-251.

Eilers, K.G., Debenport, S., Anderson, S., Fierer, N., 2012. Digging deeper to find unique microbial communities: the strong effect of depth on the structure of bacterial and archaeal communities in soil. Soil Biology \& Biochemistry 50, 58-65.

Eisenhauer, N., Ferlian, O., Craven, D., Hines, J., Jochum, M., 2019. Ecosystem responses to exotic earthworm invasion in northern North American forests. Research Ideas and Outcomes 5, e34564
Eisenhauer, N., Lanoue, A., Strecker, T., Scheu, S., Steinauer, K., Thakur, M.P., Mommer, L., 2017. Root biomass and exudates link plant diversity with soil bacterial and fungal biomass. Scientific Reports 7, 44641.

Eisenhauer, N., Migunova, V.D., Ackermann, M., Ruess, L., Scheu, S., 2011. Changes in plant species richness induce functional shifts in soil nematode communities in experimental grassland. PLoS One 6, e24087.

Eisenhauer, N., Reich, P.B., 2012. Above- and below-ground plant inputs both fuel soil food webs. Soil Biology \& Biochemistry 45, 156-160.

Elfstrand, S., Lagerlöf, J., Hedlund, K., Mårtensson, A., 2008. Carbon routes from decomposing plant residues and living roots into soil food webs assessed with ${ }^{13} \mathrm{C}$ labelling. Soil Biology \& Biochemistry 40, 2530-2539.

Ferris, H., Bongers, T., de Goede, R.G.M., 2001. A framework for soil food web diagnostics: extension of the nematode faunal analysis concept. Applied Soil Ecology 18, 13-29.

Freschet, G.T., Cornwell, W.K., Wardle, D.A., Elumeeva, T.G., Liu, W., Jackson, B.G., Onipchenko, V.G., Soudzilovskaia, N.A., Tao, J., Cornelissen, J.H.C., 2013. Linking litter decomposition of aboveand below-ground organs to plant-soil feedbacks worldwide. Journal of Ecology 101, 943-952.

Glavatska, O., Müller, K., Butenschoen, O., Schmalwasser, A., Kandeler, E., Scheu, S., Totsche, K.U., Ruess, L., 2017. Disentangling the root- and detritus-based food chain in the micro-food web of an arable soil by plant removal. PLoS One 12 , e0180264.

Gransee, A., Wittenmayer, L., 2000. Qualitative and quantitative analysis of water soluble root exudates in relation to plant species and development. Journal of Plant Nutrition and Soil Science 163, 381-385.

Hsiao, C.J., Sassenrath, G.F., Zeglin, L.H., Hettiarachchi, G.M., Rice, C.W., 2018. Vertical changes of soil microbial properties in claypan soils. Soil Biology \& Biochemistry 121, 154-164.

Jones, D.L., Kemmitt, S.J., Wright, D., Cuttle, S.P., Bol, R., Edwards, A.C., 2005. Rapid intrinsic rates of amino acid biodegradation in soils are unaffected by agricultural management strategy. Soil Biology \& Biochemistry 37, 1267-1275.

Kalinkat, G., Brose, U., Rall, B.C., 2013. Habitat structure alters topdown control in litter communities. Oecologia 172, 877-887.

Kaneda, S., Kaneko, N., 2011. Influence of Collembola on nitrogen mineralization varies with soil moisture content. Soil Science and Plant Nutrition 57, 40-49.

Keith, A.M., Brooker, R.W., Osler, G.H.R., Chapman, S.J., Burslem, D. F.R.P., van der Wal, R., 2009. Strong impacts of belowground tree inputs on soil nematode trophic composition. Soil Biology \& Biochemistry 41, 1060-1065.

Kudrin, A.A., 2017. Effects of low quantities of added labile carbon on soil nematodes in intact forest soil microcosms. European Journal of Soil Biology 78, 29-37.

Lazarova, S.S., de Goede, R.G.M., Peneva, V.K., Bongers, T., 2004. Spatial patterns of variation in the composition and structure of nematode communities in relation to different microhabitats: a case study of Quercus dalechampii Ten. forest. Soil Biology \& Biochemistry 36, 701-712. 
Liu, J., Chen, Y., Du, C., Liu, X., Ma, Q., Zhang, X., Wang, D., 2019. Interactive effects of nitrogen addition and litter on soil nematodes in grassland. European Journal of Soil Science 70, 697-706.

Malik, A.A., Chowdhury, S., Schlager, V., Oliver, A., Puissant, J., Vazquez, P.G.M., Jehmlich, N., von Bergen, M., Griffiths, R.I., Gleixner, G., 2016. Soil fungal:bacterial ratios are linked to altered carbon cycling. Frontiers in Microbiology 7, 1247.

Moore, J.C., Berlow, E.L., Coleman, D.C., de Ruiter, P.C., Dong, Q., Hastings, A., Johnson, N.C., McCann, K.S., Melville, K., Morin, P. J., Nadelhoffer, K., Rosemond, A.D., Post, D.M., Sabo, J.L., Scow, K.M., Vanni, M.J., Wall, D.H., 2004. Detritus, trophic dynamics and biodiversity. Ecology Letters 7, 584-600.

Moradi, J., John, K., Vicentini, F., Veselá, H., Vicena, J., Ardestani, M. M., Frouz, J., 2020. Vertical distribution of soil fauna and microbial community under two contrasting post mining chronosequences: Sites reclaimed by alder plantation and unreclaimed regrowth. Global Ecology and Conservation 23, e01165.

Neher, D.A., Darby, B.J., 2009. General community indices that can be used for analysis of nematode assemblages, In: Wilson, M.J., Kakouli-Duarte, T., eds., Nematodes as Environmental Indicators. CABI, Wallingford, pp. 107-123.

Pausch, J., Hünninghaus, M., Kramer, S., Scharroba, A., Scheunemann, N., Butenschoen, O., Marhan, S., Bonkowski, M., Kandeler, E., Scheu, S., Kuzyakov, Y., Ruess, L., 2018. Carbon budgets of top- and subsoil food webs in an arable system. Pedobiologia 69, 29-33.

Pollierer, M.M., Langel, R., Körner, C., Maraun, M., Scheu, S., 2007. The underestimated importance of belowground carbon input for forest soil animal food webs. Ecology Letters 10, 729-736.

Potapov, A.M., Goncharov, A.A., Semenina, E.E., Korotkevich, A.Y., Tsurikov, S.M., Rozanova, O.L., Anichkin, A.E., Zuev, A.G., Samoylova, E.S., Semenyuk, I.I., Yevdokimov, I.V., Tiunov, A.V., 2017. Arthropods in the subsoil: Abundance and vertical distribution as related to soil organic matter, microbial biomass and plant roots. European Journal of Soil Biology 82, 88-97.

Rooney, N., McCann, K., Gellner, G., Moore, J.C., 2006. Structural asymmetry and the stability of diverse food webs. Nature 442 , 265-269.

Ruess, L., Ferris, H., 2004. Decomposition pathways and successional changes. Nematology Monographs \& Perspectives 2, 547556.

Ruf, A., Kuzyakov, Y., Lopatovskaya, O., 2006. Carbon fluxes in soil food webs of increasing complexity revealed by ${ }^{14} \mathrm{C}$ labelling and ${ }^{13} \mathrm{C}$ natural abundance. Soil Biology \& Biochemistry 38, 23902400.

Saj, S., Mikola, J., Ekelund, F., 2009. Species-specific effects of live roots and shoot litter on soil decomposer abundances do not forecast plant litter-nitrogen uptake. Oecologia 161, 331-341.

Sauvadet, M., Chauvat, M., Cluzeau, D., Maron, P.A., Villenave, C., Bertrand, I., 2016. The dynamics of soil micro-food web structure and functions vary according to litter quality. Soil Biology \& Biochemistry 95, 262-274.

Sayer, E.J., 2006. Using experimental manipulation to assess the roles of leaf litter in the functioning of forest ecosystems. Biological Reviews of the Cambridge Philosophical Society 81, 1-31.

Scharroba, A., Kramer, S., Kandeler, E., Ruess, L., 2016. Spatial and temporal variation of resource allocation in an arable soil drives community structure and biomass of nematodes and their role in the micro-food web. Pedobiologia 59, 111-120.

Shao, Y., Zhang, W., Eisenhauer, N., Liu, T., Xiong, Y., Liang, C., Fu, S., 2017. Nitrogen deposition cancels out exotic earthworm effects on plant-feeding nematode communities. Journal of Animal Ecology 86, 708-717.

Sradnick, A., Oltmanns, M., Raupp, J., Joergensen, R.G., 2014. Microbial residue indices down the soil profile after long-term addition of farmyard manure and mineral fertilizer to a sandy soil. Geoderma 226-227, 79-84.

Stone, M.M., DeForest, J.L., Plante, A.F., 2014. Changes in extracellular enzyme activity and microbial community structure with soil depth at the Luquillo Critical Zone Observatory. Soil Biology \& Biochemistry 75, 237-247.

Sun, T., Wang, Y., Hui, D., Jing, X., Feng, W., 2020b. Soil properties rather than climate and ecosystem type control the vertical variations of soil organic carbon, microbial carbon, and microbial quotient. Soil Biology \& Biochemistry 148, 107905.

Sun, Y., Chen, H.Y.H., Jin, L., Wang, C., Zhang, R., Ruan, H., Yang, $J$., 2020a. Drought stress induced increase of fungi:bacteria ratio in a poplar plantation. Catena 193, 104607.

Tian, Q., Wang, X., Wang, D., Wang, M., Liao, C., Yang, X., Liu, F., 2017. Decoupled linkage between soil carbon and nitrogen mineralization among soil depths in a subtropical mixed forest. Soil Biology \& Biochemistry 109, 135-144.

Wan, S., Zhang, C., Chen, Y., Zhao, J., Zhu, X., Wu, J., Zhou, L., Lin, Y., Liu, Z., Fu, S., 2015. Interactive effects of understory removal and fertilization on soil respiration in subtropical Eucalyptus plantations. Journal of Plant Ecology 8, 284-290.

Wang, Q., He, T., Wang, S., Liu, L., 2013. Carbon input manipulation affects soil respiration and microbial community composition in a subtropical coniferous forest. Agricultural and Forest Meteorology 178-179, 152-160.

Yang, L., Liu, N., Ren, H., Wang, J., 2009. Facilitation by two exotic Acacia: Acacia auriculiformis and Acacia mangium as nurse plants in South China. Forest Ecology and Management 257, 17861793.

Zhang, P., Li, B., Wu, J., Hu, S., 2019. Invasive plants differentially affect soil biota through litter and rhizosphere pathways: a metaanalysis. Ecology Letters 22, 200-210.

Zhang, P., Neher, D.A., Li, B., Wu, J., 2018. The impacts of above- and belowground plant input on soil microbiota: invasive Spartina alterniflora versus native Phragmites australis. Ecosystems (New York, N.Y.) 21, 469-481.

Zhang, X., Dong, X., Liang, W., 2010. Spatial distribution of soil nematode communities in stable and active sand dunes of Horqin sandy land. Arid Land Research and Management 24, 68-80.

Zhao, C., Guo, E., Shao, Y., Zhang, W., Zhang, C., Liu, Y., Li, Y., Zou, X., Fu, S., 2021. Impacts of litter addition and root presence on soil nematode community structure in a young Eucalyptus plantation in southern China. Forest Ecology and Management 479, 118633.

Zhao, C., Miao, Y., Yu, C., Zhu, L., Wang, F., Jiang, L., Hui, D., Wan, S., 2015b. Soil microbial community composition and respiration along an experimental precipitation gradient in a semiarid steppe. Scientific Reports 6, 24317. 
Zhao, C., Sun, F., Yu, C., Zhu, L., Li, Y., Zhou, Z., Yang, G., Wang, W., Miao, R., 2018. Soil nematode trophic groups in four different plantations in southern China: implications for restoration. Polish Journal of Environmental Studies 27, 1379-1386.

Zhao, C., Zhao, J., Wu, J., Classen, A.T., Li, Y., Lou, Y., Zhang, W., Jing, X., Shao, Y., Fu, S., 2019. Bamboo forest management leads to a shift in the soil energy channel. Geoderma 353, 201-203.
Zhao, J., Li, D., Fu, S., He, X., Fu, Z., Zhang, W., Wang, K., 2016. Using the biomasses of soil nematode taxa as weighting factors for assessing soil food web conditions. Ecological Indicators 60, 310316.

Zhao, J., Zhao, C., Wan, S., Wang, X., Zhou, L., Fu, S., 2015a. Soil nematode assemblages in an acid soil as affected by lime application. Nematology 17, 179-191. 